\title{
ANALISIS KEMAMPUAN BERPIKIR KRITIS MATEMATIS MAHASISWA CALON GURU MATEMATIKA MENGGUNAKAN SOAL LIMIT FUNGSI BERBASIS HOTS
}

\section{ANALYSIS OF THE MATHEMATICS STUDENT TEACHERS' CRITICAL THINKING SKILL USING HOTS-BASED LIMIT OF FUNCTION PROBLEMS}

\author{
Sumargiyani $^{\mathrm{a}}$, Afit Istiandaru ${ }^{\mathrm{b}}$, Muhammad Asrori Ainurrahman ${ }^{\mathrm{c}}$ \\ a Program Studi Pendidikan Matematika FKIP Universitas Ahmad Dahlan \\ Jl. Ahmad Yani, Tamanan, Banguntapan, Bantul, DIY, sumargiyani@pmat.uad.ac.id \\ b Program Studi Pendidikan Matematika FKIP Universitas Ahmad Dahlan \\ Jl. Ahmad Yani, Tamanan, Banguntapan, Bantul, DIY, afit.istiandaru@pmat.uad.ac.id \\ ${ }^{\mathrm{c}}$ Jurusan Matematika FMIPA Universitas Negeri Yogyakarta \\ Jl. Colombo No. 1 Karangmalang, Caturtunggal, Sleman, DIY, m.asrori016@gmail.com
}

\begin{abstract}
ABSTRAK
Penelitian ini bertujuan untuk mendeskripsikan kemampuan berpikir kritis matematis mahasiswa calon guru matematika menggunakan soal limit fungsi berbasis HOTS. Aspek-aspek kemampuan yang dianalisis meliputi: (1) menggeneralisasi masalah, (2) mengidentifikasi masalah, (3) merumuskan masalah ke dalam model matematika, (4) mendeduksi dengan menggunakan prinsip serta memberikan kesimpulan dari permasalahan, dan (5) memberikan penjelasan lanjut. Penelitian ini adalah penelitian deskriptif kualitatif yang melibatkan sembilan mahasiswa Program Studi Pendidikan Matematika FKIP Universitas Ahmad Dahlan Kelas B Tahun Akademik 2019/2020 sebagai subjek. Pengumpulan data dilakukan menggunakan tes berpikir kritis matematis dan wawancara tak terstruktur pada materi limit fungsi. Data dianalisis dengan melakukan reduksi data, menyajikan data, dan menarik simpulan atau verifikasi. Hasil penelitian menunjukkan bahwa: (1) sebagian mahasiswa mampu menggeneralisasi dan mengidentifikasi masalah pembuktian limit fungsi dua pihak, namun masih banyak yang belum mampu merumuskan masalah ke dalam model matematika; (2) sebagian mahasiswa mampu menggeneralisasi dan mengidentifikasi masalah pembuktian limit fungsi satu pihak, namun masih banyak yang belum mampu memahami konsep dasar limit fungsi satu pihak dan merumuskan masalah ke dalam model matematika; (3) banyak mahasiswa yang mampu menyelesaikan masalah non pembuktian, menerapkan prosedur dan menarik simpulan pemecahan masalah, namun hanya sebagian mahasiswa yang mampu menyelesaikan masalah pembuktian limit fungsi satu pihak, melakukan generalisasi, dan menggunakan simbol dengan tepat.
\end{abstract}

Kata Kunci : berpikir kritis, HOTS, limit fungsi.

\begin{abstract}
This research aims to describe the student teachers' higher order thinking skills using HOTSbased limit of function. The aspects analyzed include: (1) generalizing, (2) identifying, (3) formulating problems into mathematical model, (4) making deduction and conclusion using principles, and (5) providing extended explanation. It was a qualitative descriptive research which involved nine student teachers of Class B Mathematics Education Department of Universitas Ahmad Dahlan in the
\end{abstract}


2019/2020 academic year as its subject. The data were collected using mathematical critical thinking test of function limit and unstructured interview. Then, the collected data were analyzed following the steps of data reduction, data presentation, and drawing conclusion or verification. The results showed that: (1) some students were able to generalize and identify the problem of proving the two sided limit of function, but there were still many who were not able to formulate problems into a mathematical model; (2) some students are able to generalize and identify problems of proving the one sided limit of function, but there are still many who are not able to understand the basic concept of one-sided limit of function and formulate problems into mathematical models; (3) there are many students who are able to solve nonproving problems, apply procedures and draw conclusions on problem solving, but only some students are able to solve the problem of proving the one sided limit of function, making generalization, and using symbols appropriately.

Keywords : critical thinking skill, higher order thinking skills, limit of function.

\section{Pendahuluan}

Kemampuan berpikir kritis salah satu bagian yang sangat penting untuk dimiliki di era industri 4.0 dan pembelajaran abad ke-21 (Syafina dan Suparman, 2019; Dhayanti et al, 2018; Fuad, et al, 2017) Pengembangan kemampuan berpikir kritis sebagai salah satu indikator yang penting untuk ditekankan pada pembelajaran matematika di abad ke21.

Hal tersebut, karena kemampuan berpikir kritis dapat meningkatkan kualitas dalam pembelajaran matematika menjadi lebih baik dan bermakna (Dhayanti et al, 2018; Chikiwa dan Schafer, 2018; Firdaus et al, 2015).

Pentingnya berpikir kritis menjadi salah satu tujuan pembelajaran matematika yakni matematika sebagai suatu ilmu dasar untuk melatih mahasiswa untuk berpikir secara logis, analitis, sistematis, kritis, inovatif, kreatif, dan kemampuan berpikir tersebut dapat terjadi secara bersama-sama
(Kusumaningrum dan Suparman, 2020; Susilo et al, 2019).

Proses berpikir kritis matematika dimulai dari mahasiswa membuat pernyataan yang berkaitan dengan masalah, kemudian menghubungkan masalah tersebut dengan pengetahuan dan pengalaman yang telah dimilikinya (Widyaningtyas et al, 2015; Zetriuslita, 2016). Adapun indikator kemampuan berpikir kritis dalam matematika menurut Widyaningtyas et al (2015) meliputi (1) menghubungkan elemenelemen masalah dan merumuskannya ke dalam solusi; (2) menganalisis data untuk mengidentifikasi dan mengambil keputusan terkait masalah; (3) menganalisis unsurunsur yang termuat dalam hubungan; (4) menganalisis hubungan untuk memeriksa dan menginteraksikan antara unsur-unsur masalah, serta membuat keputusan sebagai penyelesaian masalah; (5) menciptakan atau membuat komentar dan saran sesuai dengan 
yang telah dipelajari; dan (6) mengevaluasi penyelasaian masalah melalui hasil atau jawaban dalam ujian. Sehingga, pembelajaran matematika dapat terintegrasikan melalui indikator-indikator kemampuan berpikir kritis.

Kalkulus adalah salah satu materi matematika yang merupakan pengembangan dari aritmatika, aljabar, dan geometri (Susilo et al, 2019). Salah satu fokus utama kalkulus adalah kalkulus diferensial yang membahas materi turunan khususnya limit fungsi. Kalkulus diferensial dibangun dari konsep limit fungsi, karena apabila gagal memahami konsep limit fungsi maka menyebabkan kesulitan dalam mempelajari materi kalkulus (Susilo et al, 2019).

Berdasarkan pentingnya materi limit fungsi maka perlu dikaji kemampuan mahasiswa dalam berpikir kritis matematis terkait materi tersebut. Untuk kemampuan berpikir kritis dalam pembelajaran matematika diperlukan suatu instrument yang dapat mengembangkan kemampuan berpikir kritis, salah satunya melalui penilaian HOTS (Widana et al, 2018; Peter, 2012). Penilaian HOTS mengukur kemampuan untuk menganalisis, mengevaluasi, dan menciptakan (Widana et al, 2018; Pratama dan Retnawati, 2018). Kemampuan berpikir kritis sebagai salah satu kemampuan berpikir tingkat tinggi atau Higher Order Thinking Skills (HOTS) (Yuliani dan Saragih, 2015). HOTS dalam pembelajaran matematika lahir dari serangkaian proses yang kontinu dan konsisten jadi bukan hanya berorientasi pada hasil, sehingga bentuk soal HOTS adalah soal uraian (Widana et al, 2018; Yuliani dan Saragih, 2015).

Berdasarkan uraian diatas, peneliti selaku pengampu mata kuliah kalkulus tertarik untuk menganalisis kemampuan berpikir kritis mahasiswa berdsarkan indikator: (1) kemampuan menggeneralisasi, (2) kemampuan mengidentifikasi, kemampuan merumuskan masalah ke model matematika, (4) kemampuan mendeduksi dengan menggunakan prinsip, memberikan kesimpulan dari permasalahan, dan (5) kemampuan memberikan penjelasan lanjut.

\section{Metode Penelitian}

Penelitian ini termasuk penelitian kualitatif. Tempat dilaksanakan penelitian di Program studi Pendidikan Matematika FKIP UAD Yogyakarta, dengan pelaksanaan pada semester genap Tahun Akademik 2019/2020. Ada sebanyak sembilan orang mahasiswa yang dijadikan subyek penelitian yang diambil dari 25 orang mahasiswa kelas B Prodi Pendidikan Matematika FKIP 
Universitas Ahmad Dahlan Tahun Akademik 2019/2020 yang mengambil mata kuliah Kalkulus Diferensial. Intrumen yang digunakan tes yang berbentuk soal uraian berbentuk HOTS dan instrument non tes berupa lembar observasi dan pedoman wawancara yang telah divalidasikan ke dosen rumpun analisis di prodi Pendidikan Matematika UAD. Pelaksanaan tes dilakukan melalui online dalam jangka waktu 90 menit dan wawancara dilakukan lewat telepon disebabkan kegiatan penelitian ini dilakukan di masa pandemic Covid-19. Analisis data digunakan reduksi data, sajian data, dan penarikan simpulan atau verifikasi.

\section{Hasil dan Pembahasan}

Penelitian ini telah dilakukan dengan subyek diambil dari mahasiswa kelas B pada tanggal 8 Juli 2020. Dari jumlah mahasiswa sebanyak 25 orang dikelompokkan menjadi tiga kelompok level tinggi, sedang dan rendah didasarkan pada hasil nilai UTS kalkulus diferensial, dengan hasil seperti pada Tabel 1 berikut.

Tabel 1. Jumlah Responden Berdasarkan Level

\begin{tabular}{lcc}
\hline Level & Interval & Jumlah \\
\hline Tinggi & $\mathrm{M}>84,72$ & 5 \\
Sedang & $54,8 \leq \mathrm{M} \leq 84,72$ & 14 \\
Rendah & $\mathrm{M}<54,8$ & 6 \\
\hline
\end{tabular}

Dari masing-masing level diambil tiga mahasiswa secara acak sebagai subyek penelitian.

Dari ketiga soal limit fungsi yang berbentuk uraian yang diberikan untuk diketahui analisis kemampuan berpikir kritis matematis mahasiswa telah diperoleh hasil berikut pada Gambar 1.



Gambar 1. Persentase Kemampuan Berpikir Kritis per Indikator.

Dari grafik di atas terlihat bahwa kemampuan berpikir kritis mahasiswa terbesar pada soal nomor 3. Pada soal nomor 1 mahasiswa kemampuan berpikir kritis masih kurang. Rata -rata kemampuan berpikir kritis matematis dapat dilihat pada Gambar 2 berikut.

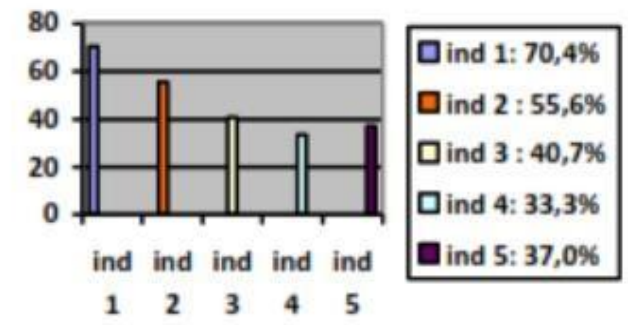

Gambar 2. Rata-rata Persentase Kemampuan Berpikir Kritis Mahasiswa. 
Keterangan :

Ind 1 : Kemampuan menggeneralisasi.

Ind 2 : Kemampuan mengidentifikasi.

Ind 3 : Kemampuan merumuskan masalah ke model matematika.

Ind 4 : Kemampuan mendeduksi dengan menggunakan prinsip, memberikan kesimpulan dari permasalahan.

Ind 5 : Kemampuan memberikan penjelasan lanjut.

Dari Gambar 2, terlihat bahwa kemampuan berpikir kritis mahasiswa yang terendah pada indikator 4 yaitu kemampuan mendeduksi dengan menggunakan prinsip, memberikan kesimpulan dan permasalahan.

\section{$\underline{\text { Soal Nomor } 1}$}

Berikut hasil pekerjaaan dari responden ST6 pada soal nomor 1.

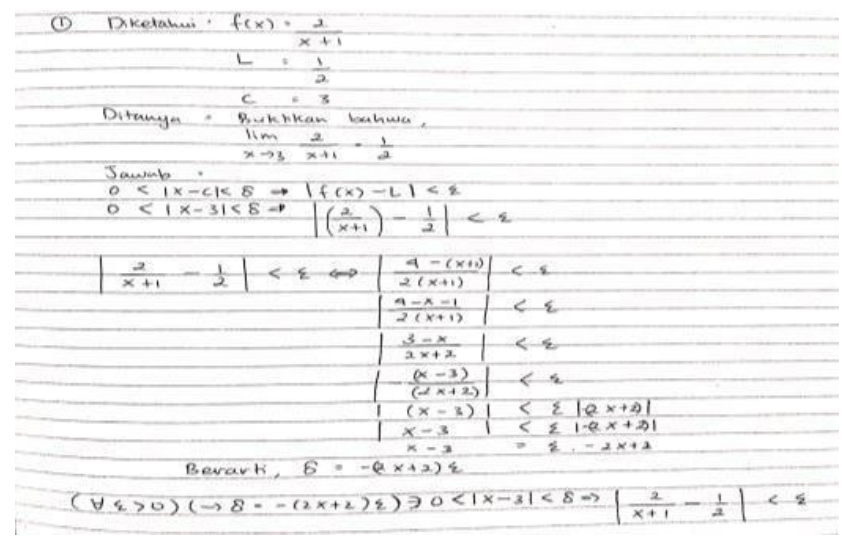

Gambar 3. Hasil Pekerjaan Mahasiswa ST6

Nomor Soal 1
Dari hasil wawancara yang dilakukan dengan ST6 diperoleh hasil berikut.

P : "Assalamualaikum mbak?”

ST6 : "Waalaikum salam, ibu"

P : "Ibu mau tanya untuk soal nomor satu paham nggak apa yang diketahui dan ditanyakan ?"

ST6 : “ Yang diketahui limit fungsi dengan $\mathrm{L}$ sama dengan $1 / 2$ dan $\mathrm{c}$ sama dengan tiga, dan disuruh membuktikan limit fungsi “

P : "Apa konsep dasar yang kalian gunakan untuk mengerjakan soal nomor 1?"

ST6 : "Saya menggunakan pembuktian limit, yang epsilon dan delta"

P : "Apa maksud pembuktian limit epsilon dan delta?"

ST6 : "Itu Bu, yang pakai definisi limit fungsi, yang ada delta dan epsilonnya itu"

P : "Untuk pemakaian simbol dalam mengerjakan soal ini bingung nggak?"

ST6 : "Paham, cuman membaca simbol nya yang bingung"

P : : "Makna dari masing-masing simbol yang kalian gunakan, apakah sudah paham?”

ST6 : "Sebagian saja yang paham, seperti delta dan epsilon itu paham, yang 
belum simbol yang itu untuk setiap yang kaya huruf A terbalik bu”.

P : "Langkah-langkah nya apakah itu sudah selesai ?"

ST6 : "Belum"

P : "Kenapa?"

ST6 : "Karena waktu kuliah itu, nilai delta variabel x nya harus dihilangkan"

P : "Kenapa tidak kamu lakukan ?"

ST6 : "Belum tahu cara menghitunya $\mathrm{Bu}$, bingung”

P : "Sebenarnya permasalahan dalam soal ini apa ?"

ST6 : "Membuktikan dengan definisi limit, sampai menemukan deltanya yang sesuai dengan epsilon, tapi saya belum karena deltamasih ada x nya"

P :“Ok, cukup mbak, assalamu'alaikum"

ST6 :"Waalaikum salam, ibu".

Dari hasil pekerjaan mahasiswa dan hasil wawancara, peneliti menganalisis berikut.

Mahasiswa mampu menggeneralisasi soal 1, dikarenakan mahasiswa mampu memahami apa yang diketahui dan yang ditanyakan. Konsep matematis ditulis secara benar, meskipun definisi limit fungsi tidak dituliskan. Penulisan simbol matematis kurang lengkap, sehingga penulisan simbol ada yang tidak jelas. Ketidaklengkapan penulisan dikarenakan mahasiswa bingung dalam pemakaian maupun pembacaan simbol matematika. Konsep yang digunakan sudah benar tetapi kurang sempurna dalam penggunaan tidak runtut dan langkah langkah dalam penyelesaian hasilnya masih salah dan dalam memberikan kesimpulan masih salah karena nilai delta tidak harus berupa angka. Mahasiswa belum mampu memberikan penjelasan lebih lanjut sesuai permasalahan yang diberikan secara benar, karena kesimpulan yang diberikan masih salah dalam pengambilan delta-nya.

\section{Soal Nomor 2 \\ Jawaban yang diberikan sembilan} responden mahasiswa untuk soal nomor dua ini bervariasi, ada enam bentuk jawaban yang diberikan oleh mahasiswa. Gambar 4 menunjukkan salah satu jawaban yang diberikan mahasiswa untuk soal nomor 2 dari responden SS3.

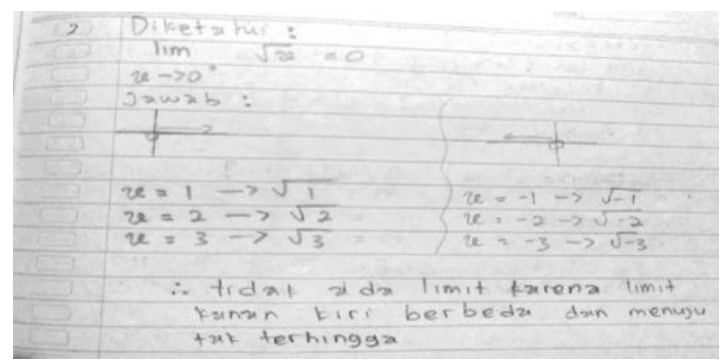

Gambar 4. Hasil Pekerjaan Mahasiswa SS3 Soal Nomor 2 
Hasil wawancara dengan mahasiswa

SS3, diperoleh hasil sebagai berikut.

P : : "Apakah kalian paham apa yang diketahui dan ditanyakan pada soal nomor dua?"

SS3 : "Yang diketahui limit fungsi dan yang ditanyakan suruh membuktikan limit fungsi “

P : "Untuk pembuktian menggunakan konsep dasar apa?"

SS3 : "Saya masukkan pakai substitusi dengan mengambil nilai $\mathrm{x}$ yang sebelah kanan nol"

P : "Terkait penggunaan simbol apakah kalian menguasai dengan baik?"

SS3 : "Tidak"

P : "Coba jelaskan pemahamanmu dalam menyelesaikan soal nomor dua?"

SS3 : "Karena soalnya $0^{+}$maka setahuku limit kanan, maka saya ambil $\mathrm{x}=1$, $\mathrm{x}=2$ dan $\mathrm{x}=3$ lama-lama hasilnya menuju tak terhingga, jadi limitnya tidak ada"

P : "Menurut kamu permasalahan dalam soal nomor dua ini apa ?"

SS3 : "Disuruh membuktikan limit fungsi, dan diselesaikan dengan subtitusi hasil limit tidak ada karena ruas kanan 0".

Dari hasil pekerjaan mahasiswa SS3 ini mahasiswa telah menuliskan pertanyaan tetapi belum mampu menentukan apa yang diketahui secara benar. Hal ini peneliti analisis berdasarkan hasil pekerjaannya bahawa digambar tertulis 0 (nol) yang diartikan mendekati nol, tetapi SS4 tidak mampu berpikir bahwa 0 (nol) tersebut didekati dari sebelah kanan saja.

Ketidakmampuan ini ternyata dikarenakan mahasiswa tidak mampu membaca simbol dari $0^{+}$sendiri. Mahasiswa mampu berpikir bahwa yang akan dikerjakan membuktikan limit fungsi, tetapi konsep dasar yang digunakan salah. Oleh karena SS4 membuktikan dengan menggunakan subtitusi dan itu merupakan langkah prosedur yang salah. Ketidakmampuan berpikir kritis mahasiswa juga ditunjukkan dari kesimpulan yang diambil. Dari hasil kesimpulan ditulis tidak ada limit, padahal soal sudah jelas limit fungsi tersebut ada dan bernilai 0 (nol). Dari jawaban-jawaban responden yang lainpun sama dengan jawaban SS4 ini, yang berpikir bahwa jika hasil limit fungsi itu 0 (nol) maka disimpulkan bahwa limit tidak ada. 


\section{$\underline{\text { Soal Nomor } 3}$}

Jawaban yang diberikan subjek ditunjukkan dengan Gambar 5.

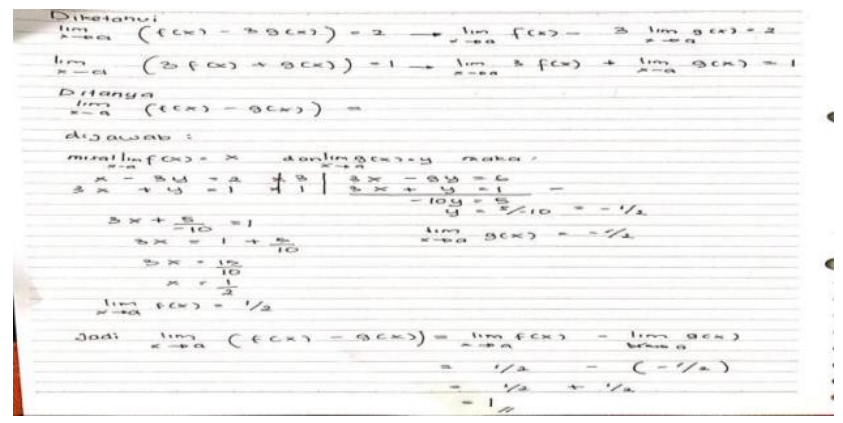

Gambar 5. Hasil Pekerjaan Mahasiswa SR8

Soal Nomor 3

Hasil wawancara dengan SR8 diperoleh sebagai berikut.

P : "Apakah kalian mampu memahami apa yang diketahui dan ditanyakan?"

SR8 : "Ya paham ibu, yang diketahui limit fungsi seperti yang saya tulis, dan yang ditanyakan $\lim \mathrm{f}(\mathrm{x})-\mathrm{g}(\mathrm{x})$ "

P : : "Konsep dasar yang kamu gunakan untuk menyelesaikan apa?"

SR8 :"Memisalkan dulu, baru dihitung"

P :"Yang dimisalkan apa?"

SR8 :" Yang diketahui dalam soal dengan $\mathrm{x}$ dan $\mathrm{y}$ "

P : "Kenapa simbol yang dipergunakan pemisalan $\mathrm{x}$ dan $\mathrm{y}$ ?”

SR8 : "Karena biasanya pemisalan menggunakan simbol $\mathrm{x}$ dan $\mathrm{y}^{\text {“ }}$
P : : Kalau kalian baca apa tidak rancu dengan yang diketahui, karena variable yang diketahui juga sudah ada $\mathrm{x}$ dan $\mathrm{y} "$

SR8 : "Oh iya bu, harusnya pakai variabel yang lain, yang tidak ada di situ $\mathrm{P}$ atau Q gitu ya bu"

P : "Betul"

P : "Kalau kalian kerjakan seperti itu, langkah yang kalian pakai menjadi benar atau salah ?"

SR8 : "Kalau dibaca jadi salah bu"

P : "Iya, kalau kalian ganti atau misalkan dengan $\mathrm{P}$ dan $\mathrm{Q}$ langkah kalian jadi benar"

SR8 :"Paham ya ?"

SR8 : "Iya"

P : "Kalau begitu langkah yang kalian gunakan untuk menyelesaikan soal nomor tiga ini pakai apa?"

SR8 : "Dimisalkan dulu yang diketahui, terus dicari pemisalannya dengan menggunakan subtitusi, terus hasil ketemu"

Hasil dari analisis kemampuan berpikir kritis mahasiswa SR8 mampu menggeneralisasi dengan adanya kemampuan memahami apa yang diketahui dan ditanyakan. Kemampuan pemahaman konsep yang dituliskan juga sudah benar. 
Kemampuan berpikir dalam penggunaan simbol matematika masih salah, dikarenakan dalam pekerjaan yang dilakukan mahasiswa mengambil pemisalan yang sama dengan variable yang diketahui yaitu variable $\mathrm{x}$. Setelah diklarifikasi melalui wawancara mahasiswa akhirnya paham bahwa pemisalan tidak boleh sama dengan variable yang diketahui agar tida rancu. Kemampuan dalam penggunaan konsep matematika sudah benar, penggunaan model matematika benar dan mahasiswa sudah mampu melakukan perhitungan secara benar. Mahasiswa juga sudah mampu berpikir bahwa hasil terakhir sudah benar dan setelah diklarifikasi melalui wawancara juga bisa menjelaskan maksud dari hasil akhir yang diperoleh dengan pertanyaan dalam soal yang diajukan.

\section{Kesimpulan}

Dari hasil penelitian ini dapat peneliti simpulkan bahwa :

1. Kemampuan berpikir kritis matematis mahasiswa pada pembuktian limit fungsi dua pihaksebagian mahasiswa mampu menggeneralisasi dan mampu mengidentifikasi masalah, tetapi kemampuan mahasiswa pada merumuskan masalah ke dalam model matematika dan menggunakan prinsip maupun menarik suatu kesimpulan masih banyak yang belum mampu.

2. Kemampuan berpikir kiritis matematis mahasiswa pada pembuktian limit fungsi satu pihak sebagian mahasiswa mampu menggeneralisasi dan mampu mengidentifikasi masalah, tetapi kemampuan untuk kemampuan mahasiswa pada pemahaman konsep dasar masih banyak yang belum bisa, kurangnya kemampuan merumuskan masalah ke dalam model matematika dan menggunakan prinsip maupun menarik suatu kesimpulan masih banyak yang belum mampu.

3. Kemampuan berpikir kiritis matematis mahasiswa pada soal yang bukan pembuktian, seperti perhitungan mahasiswa banyak yang mampu berpikir kritis (1) mahasiswa mampu mengidentifikasi masalah, menggeneralisasi, tetapi ppembuktian limit fungsi satu pihak sebagian mahasiswa mampu menggeneralisasi, kemampuan penggunaan simbol masih ada yang salah, prosedur dan penarikan kesimpulan dan menjelaskan lebih lanjut mahasiwa banyak yang sudah mampu. 


\section{Pustaka}

Chikiwa, C. and Schäfer, M., 2018. Promoting critical thinking in multilingual mathematics classes through questioning. Eurasia Journal of Mathematics, Science and Technology Education, 14(8), p.em1562.

Dhayanti, D., Johar, R. and Zubainur, C.M., 2018. Improving students' critical and creative thinking through realistic mathematics education using geometer's sketchpad. JRAMathEdu (Journal of Research and Advances in Mathematics Education), 3(1), pp.25-35.

Firdaus, F., Kailani, I., Bakar, M.N.B. and Bakry, B., 2015. Developing critical thinking skills of students in mathematics learning. Journal of Education and Learning, 9(3), pp.226-236.

Fuad, N.M., Zubaidah, S., Mahanal, S. and Suarsini, E., 2017. Improving Junior High Schools' Critical Thinking Skills Based on Test Three Different Models of Learning. International Journal of Instruction, 10(1), pp.101116.

Kusumaningrum, H and Suparman. 2020. Design of Social Arithmetic Students Worksheets With Rme Approaches To Improve Critical Thinking Ability. International Journal of Scientific \& Technology Research, 9(3), 4978-4982.

Peter, E.E., 2012. Critical thinking: Essence for teaching mathematics and mathematics problem solving skills. African Journal of Mathematics and Computer Science Research, 5(3), pp.39-43.

Pratama, G.S. and Retnawati, H., 2018, September. Urgency of higher order thinking skills (HOTS) content analysis in mathematics textbook.
In Journal of Physics: Conference Series (Vol. 1097, No. 1, p. 012147). IOP Publishing.

Susilo, B.E., Darhim, D. and Prabawanto, S., 2019. Students critical thinking skills toward concepts differences in finding area of a plane region and definite integral. Unnes Journal of Mathematics Education, 8(1), pp.1-7.

Syafina, B.P., 2019. Designing Student Worksheets To Improve Critical Thinking Ability Based On Problem Based Learning. Int. J. Sci. Technol. Res., 8, pp.1194-9.

Widana, I.W., Parwata, I., Parmithi, N.N., Jayantika, I.G.A.T., Sukendra, I.K. and Sumandya, I.W., 2018. Higher order thinking skills assessment towards critical thinking on mathematics lesson. International journal of social sciences and humanities, 2(1), pp.24-32.

Widyatiningtyas, R., Kusumah, Y.S., Sumarmo, U. and Sabandar, J., 2015. The Impact of Problem-Based Learning Approach to Senior High School Students' Mathematics Critical Thinking Ability. Indonesian Mathematical Society Journal on Mathematics Education, 6(2), pp.3038.

Yuliani, K. and Saragih, S., 2015. The Development of Learning Devices Based Guided Discovery Model to Improve Understanding Concept and Critical Thinking Mathematically Ability of Students at Islamic Junior High School of Medan. Journal of education and practice, 6(24), pp.116-128.

Zetriuslita, H.J., Ariawan, R. and Nufus, H., 2016. Students' Critical Thinking Ability: Description Based on Academic Level and Gender. Journal of Education and Practice, 7(12), pp.154-16 